\title{
Synthesis and biological evaluation of benzimidazole-linked 1,2,3-triazole congeners as agents
}

\author{
Karna Ji Harkala ${ }^{1}$, Laxminarayana Eppakayala ${ }^{{ }^{*}}$ and Thirumala Chary Maringanti ${ }^{2}$
}

\begin{abstract}
Background: Benzimidazoles and triazoles are useful structures for research and development of new pharmaceutical molecules and have received much attention in the last decade because of their highly potent medicinal activities.

Findings: A simple and efficient synthesis of triazole was carried out by treatment of 2-(4-azidophenyl)-1H-benzo[d] imidazole (6) with different types of terminal alkynes in $\mathrm{t}-\mathrm{BuOH} / \mathrm{H}_{2} \mathrm{O}$, sodium ascorbate, and $\mathrm{Zn}(\mathrm{OTf})_{2}$, screened for cytotoxicity assay and achieved good results. A series of new benzimidazole-linked 1,2,3-triazole (8a-i) congeners were synthesized through cyclization of terminal alkynes and azide. These synthesized congeners $8 a-i$ were evaluated for their cytotoxicity against five human cancer cell lines. These benzimidazole-linked 1,2,3-triazole derivatives have shown promising activity with $\mathrm{IC}_{50}$ values ranging from 0.1 to $43 \mu \mathrm{M}$. Among them, the compounds (8a, 8b, 8c, and 8e) showed comparable cytotoxicity with adriamycin control drug.

Conclusions: In conclusion, we have developed a simple, convenient, and an efficient convergent approach for the synthesis of benzimidazole-linked 1,2,3-triazole congeners as agents.
\end{abstract}

Keywords: Benzimidazole; Clic reaction; Cytotoxicity

\section{Findings}

Cancer is one of the terrible diseases which cause uncontrolled growth of group of cells. It remains a mean threat to human beings and cause death $[1,2]$. Recently, many researchers developed safe and effective ways of treating this disease and to search for novel chemotherapeutic agents. The benzimidazole nucleus is an important pharmacophore in medicinal chemistry. The synthesis of novel benzimidazole derivatives remains a main focus of modern drug discovery. The versatility of new generation benzimidazole would represent a fruitful pharmacophore for further development of better medicinal agents. Many researchers have been attracted to benzimidazole derivatives because of their wide range of biological activity. Over the past years, there is a considerable interest in the development and pharmacology of benzimidazole. They are of wide interest because of their diverse biological activity and clinical applications [3].

\footnotetext{
*Correspondence: elxnkits@yahoo.co.in

'Department of Physics and Chemistry, Mahatma Gandhi Institute of Technology, Chaitanya Bharathi, Gandipet, Hyderabad 500075, India Full list of author information is available at the end of the article
}

Some of benzimidazole derivatives have also exhibit antimicrobial [4,5], antitumor [6], anti-inflammatory [7], antihypertensive [8], and antiviral [9] activities. Benzimidazole moiety can also be extracted from naturally occurring compounds such as vitamin $B_{12}$ and its derivatives, and it is similar to the structure of purins. Pyrrolo[1,2-a]benzimidazoles represent a new class of antitumour agent exhibiting cytotoxic activity against a variety of cancer cell lines [10]. Benzimidazole containing anticancer agent, [Hoechst33342], 2'-(4-ethoxyphenyl)-5-(4-methyl-1-piperazinyl)2,5'-bis-1H-benzimidazole (1), has been reported as inhibitor of topoisomerase-I [11,12]. The other derivative of benzimidazole [Hoechst-33258] (2 Figure 1) [13,14] shows both in vitro antitumour activity, as inhibitor of DNA topoisomerase-I [15]. Hoechst 33258 a fluorescent reagent and as initially found to be active against L1210 murine leukemia. During phase I trial in humans, some responses were seen in pancreatic cancer. However, a subsequent phase II trial did not show any objective responses.

\section{实}

C 2014 Harkala et al., licensee Springer. This is an Open Access article distributed under the terms of the Creative Commons Attribution License (http://creativecommons.org/licenses/by/4.0), which permits unrestricted use, distribution, and reproduction in any medium, provided the original work is properly credited. 


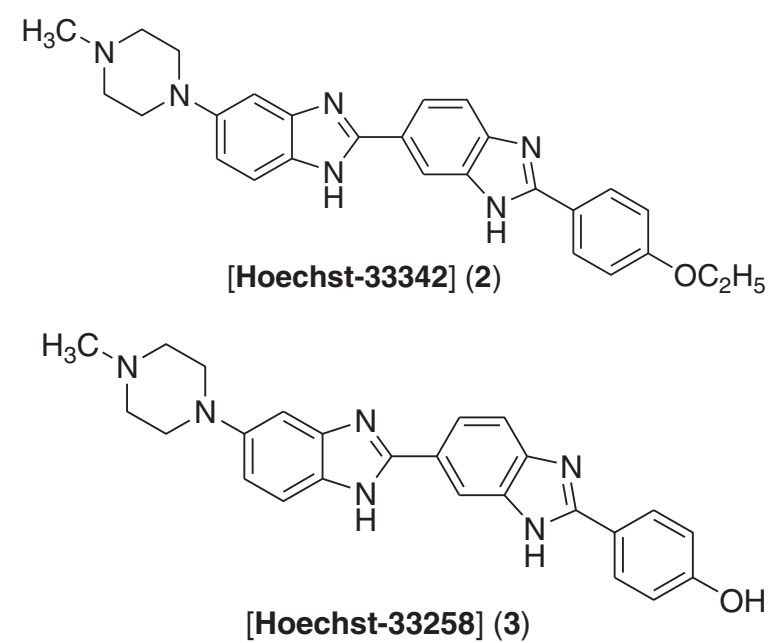

Figure 1 Biologically active benzimidazole derivatives.

In addition, triazoles also display wide spectrum of biological activities and are widely employed as pharmaceuticals and agrochemicals. Triazoles are reported to possess antibacterial, antifungal, and antihelminthic activities [16-21]. They have been regarded as an interesting unit in terms of biological activity [22,23], and some of them have also shown significant anticancer activity in many of the human cell lines [24].

In view of the biological importance of benzimidazole and 1,2,3-triazoles, to know the combined effect of both benzimidazole and 1,2,3-triazole moieties, it was considered worthwhile to synthesize certain new chemical entities having benzimidazole and 1,2,3-triazole pharmacophores in a single molecular framework, and here we have used $\mathrm{Zn}$ (OTf $)_{2}$ catalyst instead of $\mathrm{CuSO}_{4}$. All of these congeners have been evaluated for their anticancer activity against a panel of five human cancer cell lines (Figure 1).

\section{Experimental section}

All chemicals and reagents were obtained from Aldrich (Sigma-Aldrich, St. Louis, MO, USA) and Lancaster (Alfa Aesar, Johnson Matthey Company, Ward Hill, MA, USA) and were used without further purification. Reactions were monitored by TLC and performed on silica gel glass plates containing 60 F-254, and visualization on TLC was achieved by UV light or iodine indicator. ${ }^{1} \mathrm{H}$ and ${ }^{13} \mathrm{C}$ NMR spectra were recorded on Gemini Varian-VXR-unity (Palo Alto, California) (300 and $100 \mathrm{MHz}$ ) instrument. Chemical shifts (d) are reported in ppm downfield from internal TMS standard. ESI spectra were recorded on Micromass, Quattro LC (McKinley Scientific, Sparta, NJ, USA) using ESI + software with capillary voltage $3.98 \mathrm{kV}$ and ESI mode positive ion trap detector. Melting points were determined with an electrothermal melting point apparatus and are uncorrected.

\section{Chemistry}

The synthesis of novel benzimidazole linked triazole $(\mathbf{8} \mathbf{a}-\mathbf{i})$ derivatives is carried out as shown in Scheme 1. The key intermediate for the preparation of the new analogs is 2(4-azidophenyl)-1H-benzo[d]imidazole (6). The mixture
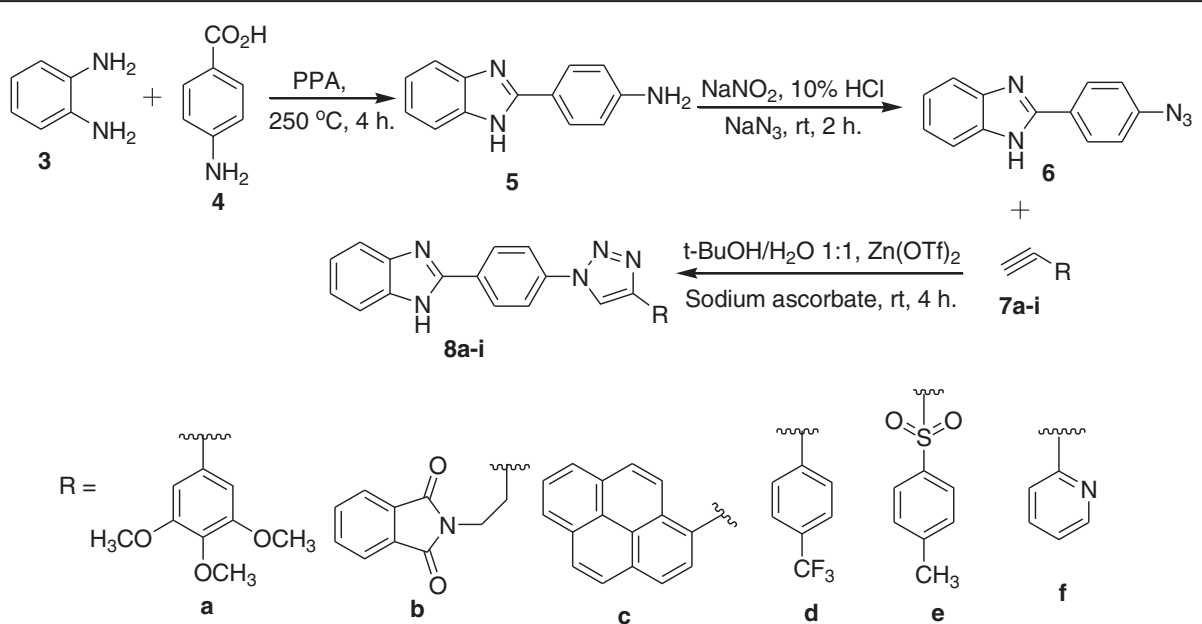<smiles>CCCCN1C(=O)c2ccccc2C1=O</smiles><smiles>Cc1ccc2ccc3cccc4ccc1c2c34</smiles><smiles>Cc1ccc(C(F)(F)F)cc1</smiles><smiles>Cc1ccc(S(C)(=O)=O)cc1</smiles><smiles>Cc1ccccn1</smiles><smiles>CCc1cccc2cc(OC)ccc12</smiles><smiles>Cc1ccc(CCCCCCCCCCCCCCCCCCCCC(C)(C)C)cc1</smiles>

Scheme 1 Synthesis 1,2,3-triazoles. 
of O-phenylenediamine (3) and 4-aminobenzoic acid (4) was mixed with a sufficient quantity of polyphosphoric acid. The resulting solution was stirred at $250^{\circ} \mathrm{C}$ for $4 \mathrm{~h}$, to afford compound $\mathbf{5}$. Compound $\mathbf{5}$ was diazotizated followed by azidation to afford compound $\mathbf{6}$. Compound $\mathbf{6}$ upon treatment with different types of terminal alkynes in $\mathrm{t}-\mathrm{BuOH} / \mathrm{H}_{2} \mathrm{O}$, sodium ascorbate, and $\mathrm{Zn}(\mathrm{OTf})_{2}$ afforded compounds (8a-i).

\section{4-(1H-Benzo[d]imidazol-2-yl)benzenamine (5)}

A mixture of the O-phenylenediamine (3) $(500 \mathrm{mg}$, $3.64 \mathrm{mmol}$ ) and the 4-aminobenzoic acid (4) (394 mg, $3.64 \mathrm{mmol}$ ) was dissolved in sufficient quantity of polyphosphoric acid (PPA). The mixture was heated slowly to $250^{\circ} \mathrm{C}$ for $4 \mathrm{~h}$, permitted to cool to room temperature, quenched with excess of $10 \% \mathrm{Na}_{2} \mathrm{CO}_{3}$ solution, and extracted with ethyl acetate. Then, the mixture was dried over anhydrous $\mathrm{Na}_{2} \mathrm{SO}_{4}$, and the crude product was purified by column chromatography with ethyl acetate/hexane (6:4) to afford pure compound 5, $946 \mathrm{mg}$ in $97 \%$ yield. Mp: $209^{\circ} \mathrm{C}$ to $211^{\circ} \mathrm{C},{ }^{1} \mathrm{H}$ NMR (300 MHz, DMSO-d ${ }_{6}$ ): $\delta 6.68$ (d, $2 \mathrm{H}$, $J=7.3 \mathrm{~Hz}$ ), 7.14 (br s, 2H), 7.50 (br s, 2H), 7.85 (d, 2H, $J=7.1 \mathrm{~Hz}$ ). IR (neat, $\mathrm{cm}^{-1}$ ): $\gamma_{\max } 404.3 ; 501.4 ; 537.9 ; 607.7$; $742.3 ; \quad 833.4 ; \quad 960.1 ; 1,009.1 ; 1,108.6 ; 1,178.6 ; 1,225.7$; $1,272.2 ; 1,397.2 ; 1,444.1 ; 1,499.2 ; 1,612.4 ; 1,701.4 ; 2,750.1$; 2,853.1; 2,921.8; 3,355.4; 3,435.0; MS (ESI): $210[\mathrm{M}+\mathrm{H}]^{+}$.

\section{2-(4-Azidophenyl)-1H-benzo[d]imidazole (6)}

The amine derivative (5) (500 $\mathrm{mg}, 2.39 \mathrm{mmol}$ ) was dissolved in $10 \%$ aq $\mathrm{HCl}$ at room temperature. This reaction mixture upon cooling to $0^{\circ} \mathrm{C}$ and addition of a solution of $\mathrm{NaNO}_{2}$ (165 mg, $2.39 \mathrm{mmol}$ ) was stirred for $10 \mathrm{~min}$ at $0^{\circ} \mathrm{C}$ to $5^{\circ} \mathrm{C}$. Sodium azide $(186 \mathrm{mg}, 2.87 \mathrm{mmol})$ was added, and the mixture was stirred at room temperature for $2 \mathrm{~h}$. The reaction was worked up by dilution with ethyl acetate. The organic layer was washed with brine and dried over $\mathrm{Na}_{2} \mathrm{SO}_{4}$. After evaporation of the solvent, the crude product was purified by column chromatography with ethyl acetate/hexane (3:7) to afford pure compound 6, $536 \mathrm{mg}$ in 95\% yield; $\mathrm{Mp}: 317^{\circ} \mathrm{C}$ to $319^{\circ} \mathrm{C},{ }^{1} \mathrm{H}$ NMR (300 $\mathrm{MHz}$, DMSO- $\left.\mathrm{d}_{6}\right): \delta 7.16$ to $7.26(\mathrm{~m}, 2 \mathrm{H}), 7.32(\mathrm{~d}, 2 \mathrm{H}, J=9.0 \mathrm{~Hz})$, 7.50 to 7.69 (dd, $2 \mathrm{H}, J=40.0,38.5 \mathrm{~Hz}), 8.22(\mathrm{~d}, 2 \mathrm{H}$, $J=8.3 \mathrm{~Hz}$ ), 12.97 (s, 1H). IR (neat, $\mathrm{cm}^{-1}$ ): $\gamma_{\max } 500.6$; 541.4; 694.3; 743.3; 838.1; 963.4; 1,011.1; 1,115.8; 1,175.5; 1,283.5; $1,395.2 ; 1,438.8 ; 1,485.1 ; 1,604.6 ; 1,726.8 ; 2,120.1 ; 2,414.9$; 2,856.9; 2,918.2; 3,055.5; 3,422.9; MS (ESI): $236[\mathrm{M}+\mathrm{H}]^{+}$.

\section{2-(4-(4-(3,4,5-Trimethoxyphenyl)-1H-1,2,3-triazol-1-yl)} phenyl)-1H-benzo[d]imidazole (8a)

A mixture of the corresponding azide 6 (200 mg, $0.85 \mathrm{mmol}$ ) and the corresponding alkyne $7 \mathbf{a}(163 \mathrm{mg}, 0.85 \mathrm{mmol})$ was dissolved in $\mathrm{t}-\mathrm{BuOH} / \mathrm{H}_{2} \mathrm{O}$ 1:1 (20 mL). Sodium ascorbate (33 mg, $20 \mathrm{~mol} \%$ ) and $\mathrm{Zn}(\mathrm{OTf})_{2}$ (300 mg, $5 \mathrm{~mol} \%$ ) were added. After stirring for $4 \mathrm{~h}$, water/ice $(40 \mathrm{~mL})$ was added.
The product was either worked up by filtration, followed by rinsing with aqueous $5 \% \mathrm{NH}_{3}(\times 3)$ and cold ether $(\times 2)$, or by extraction with dichloromethane $(4 \times 100 \mathrm{~mL})$. The combined organic layers were washed with aqueous $5 \% \mathrm{NH}_{3}$ $(3 \times 100 \mathrm{~mL})$ and brine $(100 \mathrm{~mL})$ and dried over anhydrous $\mathrm{MgSO}_{4}$. The solvent was removed in vacuo, and the crude product was purified by column chromatography with ethyl acetate/hexane (3:7) to afford pure compound 8a, $347 \mathrm{mg}$ in $95 \%$ yield. $\mathrm{Mp}: 270^{\circ} \mathrm{C}$ to $272^{\circ} \mathrm{C},{ }^{1} \mathrm{H}$ NMR $(400 \mathrm{MHz}$, $\left.\mathrm{CDCl}_{3}\right): \delta 3.71(\mathrm{~s}, 3 \mathrm{H}), 3.89(\mathrm{~s}, 6 \mathrm{H}), 7.24$ to $7.28(\mathrm{~m}, 4 \mathrm{H})$, 7.63 to $7.66(\mathrm{~m}, 2 \mathrm{H}), 8.17$ (d, $2 \mathrm{H}, J=8.4 \mathrm{~Hz}), 8.41$ (d, $2 \mathrm{H}$, $J=8.4 \mathrm{~Hz}), 9.44(\mathrm{~s}, 1 \mathrm{H}) \cdot{ }^{13} \mathrm{C} \mathrm{NMR}\left(100 \mathrm{MHz}, \mathrm{CDCl}_{3}\right): \delta$ 57.2, 61.4, 110.2, 114.8, 117.1, 122.1, 123.3, 125.3, 128.4, 129.8, 140.1, 141.8, 143.3, 148.7, 152.4, 154.1; MS (ESI): 428 $[\mathrm{M}+\mathrm{H}]^{+}$.

The other derivatives are also prepared according to the same procedure and described in Additional file 1.

\section{Biological evaluation}

In vitro cytotoxicity assay

The synthesized compounds $\mathbf{8 a - i}$ were evaluated for their anticancer activity in selected human cancer cell lines of A375, B-16, colon-205, MCF-7, and A-549 by using MTT assay. All the compounds (8a-i) exhibited significant anticancer activity with $\mathrm{IC}_{50}$ values ranging from 0.1 to $43 \mu \mathrm{M}$, while the positive control, adriamycin, demonstrated the $\mathrm{IC}_{50}$ in the range of 0.03 to $3.5 \mu \mathrm{M}$ respectively, in the cell lines employed as shown in Table 1.

\section{Procedure for MTT assay}

Toxicity of test compound in cells was determined by MTT assay based on mitochondrial reduction of yellow MTT tetrazolium dye to a highly colored blue formazan product. Cells $\left(1 \times 10^{4}\right)$ (counted by Trypan blue exclusion dye method) in 96-well plates were incubated with compounds with series of concentrations tested for $48 \mathrm{~h}$ at $37^{\circ} \mathrm{C}$ in RPMI/DMEM/MEM with $10 \%$ FBS medium. Then, the above media was replaced with $90 \mu \mathrm{l}$ of fresh serum free media and $10 \mu \mathrm{l}$ of MTT reagent $(5 \mathrm{mg} / \mathrm{ml})$,

Table 1 Cytotoxic activity (IC $\left.{ }_{50} \mu \mathrm{M}\right)$ of compounds 8a-i

\begin{tabular}{llllll}
\hline Compound & A375 & B-16 & Colon-205 & MCF-7 & A-549 \\
\hline $\mathbf{8 a}$ & 2.7 & - & 1.3 & 3.2 & 0.1 \\
$\mathbf{8 b}$ & 2.3 & 1.9 & 3.5 & 1.7 & 2.6 \\
$\mathbf{8 c}$ & 1.6 & 16 & 0.12 & 1.9 & - \\
$\mathbf{8 d}$ & - & 4.7 & 8 & - & - \\
$\mathbf{8 e}$ & 2.1 & - & 1.3 & 0.3 & 1.8 \\
$\mathbf{8 f}$ & 15 & 3.9 & 17 & - & - \\
$\mathbf{8 g}$ & 43 & - & 32 & - & 26 \\
$\mathbf{8 h}$ & - & - & - & 37 & 32 \\
$\mathbf{8 i}$ & 27 & 10 & 21 & - & - \\
ADR & 0.9 & 1.0 & 3.5 & 3.2 & 0.03 \\
\hline
\end{tabular}


and plates were incubated at $37^{\circ} \mathrm{C}$ for $4 \mathrm{~h}$, thereafter the above media was replaced with $200 \mu \mathrm{l}$ of DMSO and incubated at $37^{\circ} \mathrm{C}$ for $10 \mathrm{~min}$. The absorbance at $570 \mathrm{~nm}$ was measured on a spectrophotometer (SpectraMax, Molecular devices, Sunnyvale, CA, USA). $\mathrm{IC}_{50}$ values were determined from plot: percent inhibition (from control) versus concentration.

\section{Additional file}

Additional file 1: Experimental procedure and characterization data of all new compounds.

\section{Competing interests}

The authors declare that they have no competing interests.

\section{Acknowledgements}

We thank the management and principal of the Mahatma Gandhi Institute of Technology and the vice-chancellor and the registrar of JNT University Hyderabad for their encouragement.

\section{Author details}

'Department of Physics and Chemistry, Mahatma Gandhi Institute of Technology, Chaitanya Bharathi, Gandipet, Hyderabad 500075, India. ${ }^{2}$ Department of Chemistry, College of Engineering, Jawaharlal Nehru

Technological University, Hyderabad, Nachupally, Karimnagar 505501, India.

Received: 14 October 2014 Accepted: 30 October 2014

Published online: 02 December 2014

\section{References}

1. El-Azab AS, ElTahir KEH (2012) Design and synthesis of novel 7aminoquinazoline derivatives: antitumor and anticonvulsant activities Bio Org. Med Chem 22:1879-1885

2. El Azab AS, Al Omar MA, Abdel Aziz AAM, Abdel Aziz NI, El Sayed MAA, Aleisa AM, Sayed Ahmed MM, Abdel Hamide SG (2010) Design, synthesis and biological evaluation of novel quinazoline derivatives as potential antitumor agents: molecular docking study. Eur J Med Chem 45:4188-4198

3. Brunton LL, Lazo JS, Parker KL (2006) The pharmacological basis of therapeutics, 11th edn. Mc Graw-Hill, New York

4. Goker H, Ku C, Boykin DW, Yildiz S, Altanlar N (2002) Synthesis of some new 2-substituted-phenyl-1H-benzimidazole-5-carbonitriles and their potent activity against Candida species. Bioorg Med Chem 10:2589

5. Ozden S, Atabey D, Yildiz S, Goker H (2005) Synthesis and potent antimicrobial activity of some novel methyl or ethyl $1 \mathrm{H}$-benzimidazole-5carboxylates derivatives carrying amide or amidine groups. Bioorg Med Chem 13:1587

6. Mann J, Baron A, Opoku Boahen Y, Johansoon E, Parkmson G, Kelland LR, Neidle S (2001) A new class of symmetric bisbenzimidazole-based DNA minor groove-binding agents showing antitumor activity. J Med Chem 44:138

7. Achar KS, Hosamani KM, Seetharam HR (2010) Novel benzimidazole derivatives as expected anticancer agents. Eur J Med Chem 45:2048

8. Kumar JR, Jawahar JL, Pathak DP (2006) Synthesis and pharmacological evaluation of benzimidazole derivatives. Eur J Chem 3:278

9. Tewari AK, Mishra A (2006) Synthesis and antiviral activity of N-substituted2-subastituted benzimidazole derivatives. Ind J Chem Sec B 45:489

10. Schulz WG, Islam I, Skibo EB (1995) Pyrrolo[1,2-a]benzimidazole-based quinones and iminoquinones. The role of the 3-substituent on cytotoxicity J Med Chem 38:109

11. Chen A, Yu C, Gatto B, Liu LF (1993) Poisoning of human DNA topoisomerase I by ecteinascidin 743 , an anticancer drug that selectively alkylates DNA in the minor groove. Proc Natl Acad Sci USA 96:908131

12. Chen AY, Yu C, Bodley AL, Peng LF, Liu LF (1993) Topoisomerase I inhibitors and drug resistance. Cancer Res 53:1332
13. Kraut E, Fleming T, Segal M, Neidhart J, Behrens BC (1999) Hoechst-IR: an Imaging agent that detects necrotic tissue in vivo by binding extracellular DNA. J Invest New Drugs 9:95

14. Tolner B, Hartly JA, Hochhauser D (2001) Transcriptional regulation of topoisomerase II alpha at confluence and pharmacological modulation of expression by bis-benzimidazole drugs. Mol Pharamcol 59:699

15. Beerman TA, McHugh MM, Sigmund R, Lown JW, Rao KE, Bathini Y (1992) Effects of analogs of the DNA. Biochim Biophys Acta 1131:53-61

16. Hardman J, Limbird L, Gilman A (1996) Goodman and Gilman's. The pharmacological basis of therapeutics, 9th edn. McGraw-Hill, New York, p 988

17. Gennaro A, Remington R (1995) A mechanistic analysis of carrier-mediated oral delivery of protein therapeutics. The science and practice of pharmacy. Mack Easton PA II:1327

18. Richardson K, Whittle PJ (1984) 17 human secreted proteins. Eur Pat Appl EP 115:416, Richardson, K.; Whittle, P. (1984) J Chem Abstr 101:230544

19. Ammermann E, Loecher F, Lorenz G, Janseen B, Karbach S, Meyer N (1990) The science and practice of pharmacy. Brighton Crop Prot Conf Pests Dis 2:407

20. Ammermann E, Loecher F, Lorenz G, Janseen B, Karbach S, Meyer N (1991) The science and practice of pharmacy. Chem Abstr 114:223404h

21. Heindel ND, Reid JR (1980) 4-Amino-3-mercapto-4H-1,2,4-triazoles and propargyl aldehydes: a new route to 3-R-8-aryl-1,2,4-triazolo[3,4-b]-1,3,4thiadiazepines. J Heterocycl Chem 17:1087

22. Dehne H (1994) In: Schumann E (ed) methoden der organischen chemie (Houben-Weyl), 8th edn. Thieme, Stuttgart, p 305

23. Wamhoff H (1984) In: Katritzky AR, Rees CW (eds) In comprehensive heterocyclic chemistry, vol 5. Pergamon, Oxford, p 669

24. De Las Heras FG, Alonso R, Alonso G (1979) Alkylating nucleosides 1 . Synthesis and cytostatic activity of N-glycosyl(halomethyl)-1,2,3-triazoles. A new type of alkylating agent. J Med Chem 22:496

doi:10.1186/s13588-014-0014-x

Cite this article as: Harkala et al: Synthesis and biological evaluation of benzimidazole-linked 1,2,3-triazole congeners as agents. Organic and Medicinal Chemistry Letters 2014 4:14.

\section{Submit your manuscript to a SpringerOpen ${ }^{\circ}$ journal and benefit from:}

- Convenient online submission

$\checkmark$ Rigorous peer review

- Immediate publication on acceptance

- Open access: articles freely available online

- High visibility within the field

- Retaining the copyright to your article

Submit your next manuscript at $\mathbf{s p r i n g e r o p e n . c o m ~}$ 